\title{
The Cement Market
}

\section{Conditions of Manufacture and How They Benefit the Consumer}

\author{
By Allen E. Beals
}

SRANGELY varied is the picture presented to us

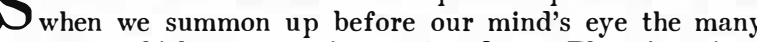
uses to which cement is put to-day. The American farmer uses it to make hen's nests that give no harbor to insect pests, that can be scrubbed and baked, thus insuring absolute disinfection. Of cement are made such varied structures as a pig sty, a freight barge, and the rampart of a fortress. Science has shown that a nest egg made of Portland cement is cheaper and more permanent than a china one, and with the same material a great government is building the world's greatest waterway. Like electricity, cement seems to be destined to render to mankind services whose extent can hardly be properly realized; and the public mind weaves a romantic future

Imagination almost quails at the vast amount of capital invested in this industrial prodigy. The investment in the United States alone is roughly estimated at $\$ 600$,000,000 , and the industry is only two score years old in America. Graphic illustration only can give the layman an idea of its phenomenal growth

Between 1870 and 1879 the total output of Portland cement in the United States was 82,000 barrels. This does not include output figures for Puzzolan and natural cements. $\Lambda$ merican mills alone turn out $6,000,000$ barrels a month to-day. This contemplates a daily consumption of 200,000 barrels, assuming that construction work, as cement manufacture, continues uninterrupted seven days in the week. This represents a total output in 1910 of $\mathbf{7 4 , 0 0 0 , 0 0 0 ~ b a r r e l s . ~ O n e ~ c o m p a n y ~ s h i p p e d ~ a ~ d a i l y ~ a v e r - ~}$ age of 5,500 barrels to the Panama Canal, or a little more than 2,000,000 barrels in 1910 .

If nine trains, each ten miles long, aggregating to a total of 14,000 freight cars, could be procured to handle this great 1910 shipment, they would barely be able to haul the total shipment in one load. If this vast quantity of Portland cement were to be placed in a single barrel proportioned exactly as an ordinary cement barrel is patterned, it would measure 294 feet high. Its weight would be $800,000,000$ pounds, or 400,000 short tons. Some idea of the size of this barrel may be gained by stating that the "Mauretania," with its 32,500 gross tonnage, would have to make several trips to carry the contents of this great cask of Portland cement, or, were it imperative to move it in one journey, it would be necessary to hitch three of these giant ocean greyhounds together abreast to make room for the machinery to propel the vessels.

Picture to yourself a barrel of Portland cement reaching to within a few feet of the top of the Eiffel tower, the top of the lantern of which is 984 feet above the street level, or so high that the famous Flatiron Building in New York city would have to be placed upon the top of the Metropolitan Building, the world's tallest inhabited structure, before an engineer could reach the top to get at the contents of the barrel. This will give a fair idea of the size of the receptacle that would be required to contain the total output of Portland cement in the Unite States in 1910 . This barrel would weigh $29,600,000,000$ pounds on the basis of 400 pounds gross to a barrel (the weight of a barrel of cement being computed at 380 pounds net to the barrel, and the barrel itself weighing 20 pounds)

One cannot conceive of such a weight until it is stated that if every man, woman and child in the United States weighed 150 pounds, the total weight of our portion of humanity, based upon the $90,000,000$ of population at the lar barrel would still have $16,100,000,000$ pounds to it advantage.

These totals are staggering when the output for the nine years between 1870 and 1879 is considered. The total output for that period would have gone into a barrel only 100 feet high or as tall as a six and one-half story building. The rate of growth and corresponding decline in prices and indication of bulk by periods in the in dustry are shown in this table:

$\begin{array}{cccr}\text { Year. } & \begin{array}{c}\text { Quantity } \\ \text { Manufactured, } \\ \text { Barrels. }\end{array} & \begin{array}{c}\text { Price per Barrel } \\ \text { Represented } \\ \text { 25 } 25 \text {-Cent Pieces. }\end{array} & \begin{array}{c}\text { Height of } \\ \text { Imaginary Barrel }\end{array} \\ 1880 & 42,000 & 12 & 81 \text { feet } \\ 1890 & 33,5,000 & 8 & 163 \text { feet } \\ 1900 & 8,413,000 & 4 & 476 \text { feet } \\ 1910 & 74,000,000 & 3 & 980 \text { feet }\end{array}$

One would suppose that under such wonderful stride in development cement producing companies would be reaping tremendous profits. Here is the tragic side of the industry.

The prospects of quick returns upon investments and the exploiting of production figures have been a source of much profit to the promoter, whether the same be true of the investor or not. There are 103 plants in this country to-day. More will start this spring. Each company is producing just as much as it can regardless of market conditions. In consequence many companies were sorely squeezed last year, when competition was conscienceless.

The following statistics show the wonderful growth of the industry and also the decadence in prices:

\begin{tabular}{rcrc} 
& $\begin{array}{c}\text { Number Barrels } \\
\text { Produced. }\end{array}$ & \multicolumn{1}{c}{$\begin{array}{c}\text { Value. } \\
\text { Price per Barrel } \\
\text { at Mill. }\end{array}$} \\
1870 to 1879 & 82,000 & $\$ 246,000$ & $\$ 3.00$ \\
1880 & 42,000 & 126,000 & 3.00 \\
1881 & 60,000 & 150,000 & 2.50 \\
1882 & 85,000 & 191,250 & 2.01
\end{tabular}

$\begin{array}{lcrc} & \begin{array}{c}\text { Number Barrels } \\ \text { Produced. }\end{array} & \begin{array}{c}\text { Value. } \\ 1883\end{array} & \begin{array}{c}\text { Price per Barrel } \\ \text { at Mill. }\end{array} \\ 1884 & 100,000 & \$ 193,500 & 2.15 \\ 1885 & 150,000 & 210.000 & 2.10 \\ 1886 & 150,000 & 292,500 & 1.95 \\ 1887 & 250,000 & 487,000 & 1.95 \\ 1888 & 250,000 & 480,000 & 1.95 \\ 1889 & 300,000 & 500,000 & 1.95 \\ 1890 & 335,500 & 704,000 & 1.67 \\ 1891 & 454,813 & 967,429 & 2.13 \\ 1892 & 547,440 & 1,153,600 & 2.11 \\ 1893 & 590,625 & 1,158,138 & 1.91 \\ 1894 & 789,575 & 1.283,473 & 1.73 \\ 1895 & 990,324 & 1,586,830 & 1.60 \\ 1896 & 1,543,023 & 2,424,011 & 1.57 \\ 1897 & 2,677,775 & 4,315,891 & 1.61 \\ 1898 & 3,692,284 & 5,970,773 & 1.62 \\ 1899 & 5,652,866 & 8,074,371 & 1.43 \\ 1900 & 8,483,020 & \mathbf{9 , 2 8 0 , 5 2 5} & 1.09 \\ 1901 & 12,711,225 & 12,532,360 & .99 \\ 1902 & 17,230,644 & 20,864,078 & 1.21 \\ 1903 & 22,342,973 & 27,713,319 & 1.24 \\ 1904 & 26,505,881 & 23,355,119 & .98 \\ 1905 & 35,246,812 & 33,245,867 & .96 \\ 1906 & 46,463,424 & 52,466,186 & 1.13 \\ 1907 & 48,875,310 & 53,992,551 & 1.11 \\ 1908 & 51,072,912 & 43,547,679 & .85 \\ 1909 & 62,508,461 & 50510,385 & .81 \\ 1910^{*} & 74,000,000 & 55,500,000 & \dagger \\ & & & \end{array}$

It will be observed that the quantity of cement manufactured in 1910 showed an increase in production of 21.3 over 1909 , but the price was lower than it has ever gone.

FINDING NEW OUTLETS.

Many companies were forced to sell their product below cost during 1910 as a result of a culmination of conditions which had been foreseen but treated with more or less indifference for several years. The curtain went up on the tragedy early in 1908 , when manufacturers began to feel the tremendous impetus in the market. of the producers being territory selling lindled persen, and in the field.

The United States Steel Company found it somewhat difficult to get rid of the great piles of slag from its (Continued on page 201.)

* Estimated. able until after the first of April when the U. S. Geological
Survey makes its report. The probabilities are that it will be

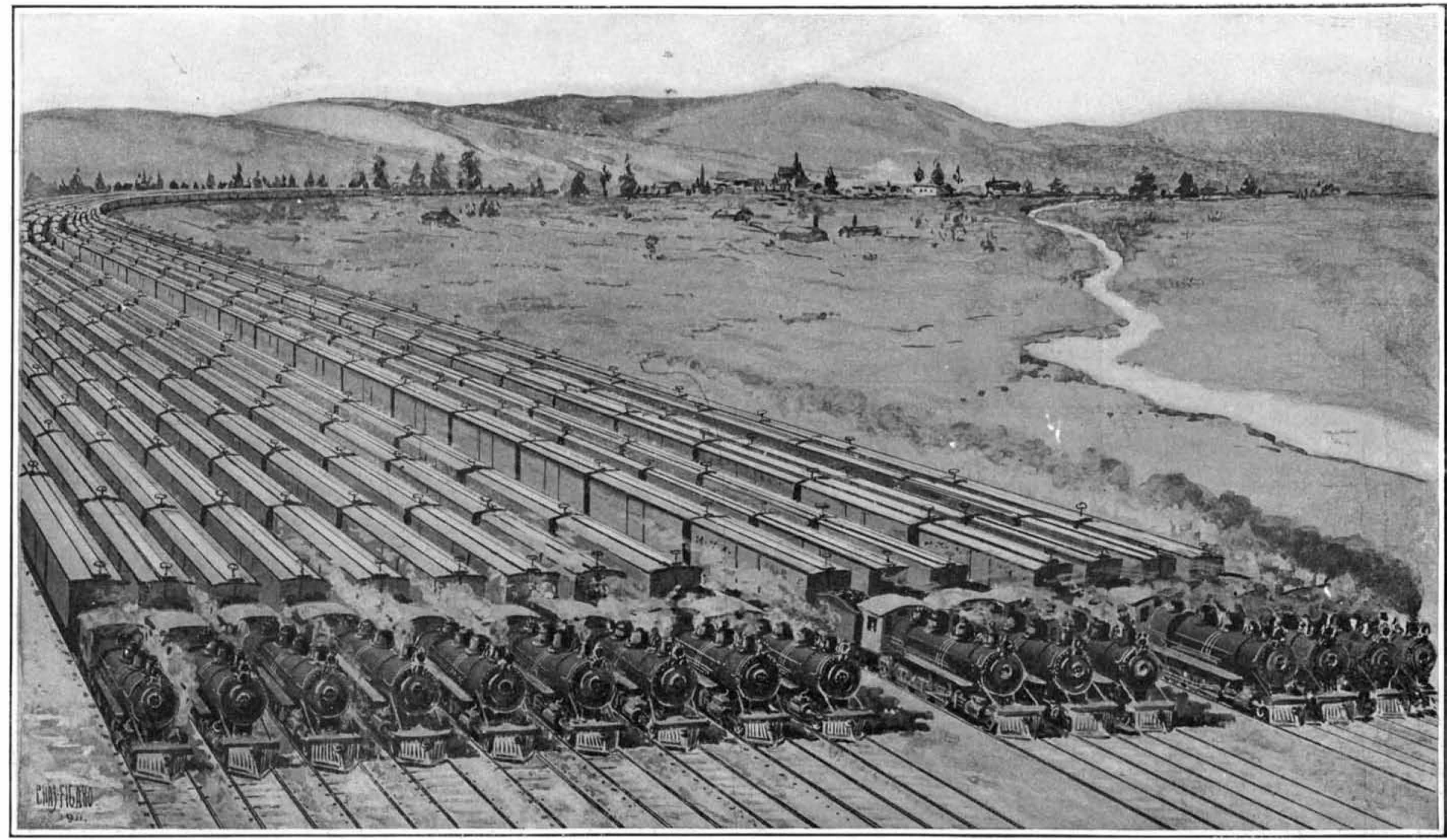

To Panama Canal in 1910: 2,100,000 barrels of cement which would fill consisting of 1400 cars.
constes 10 mileng
To Florida-Key West Railroad: To Ashokan dam: - 1,000,000 800,000 barrels of cement. Three barrels. Four trains over
trains each over 10 miles long, 10 miles long. 

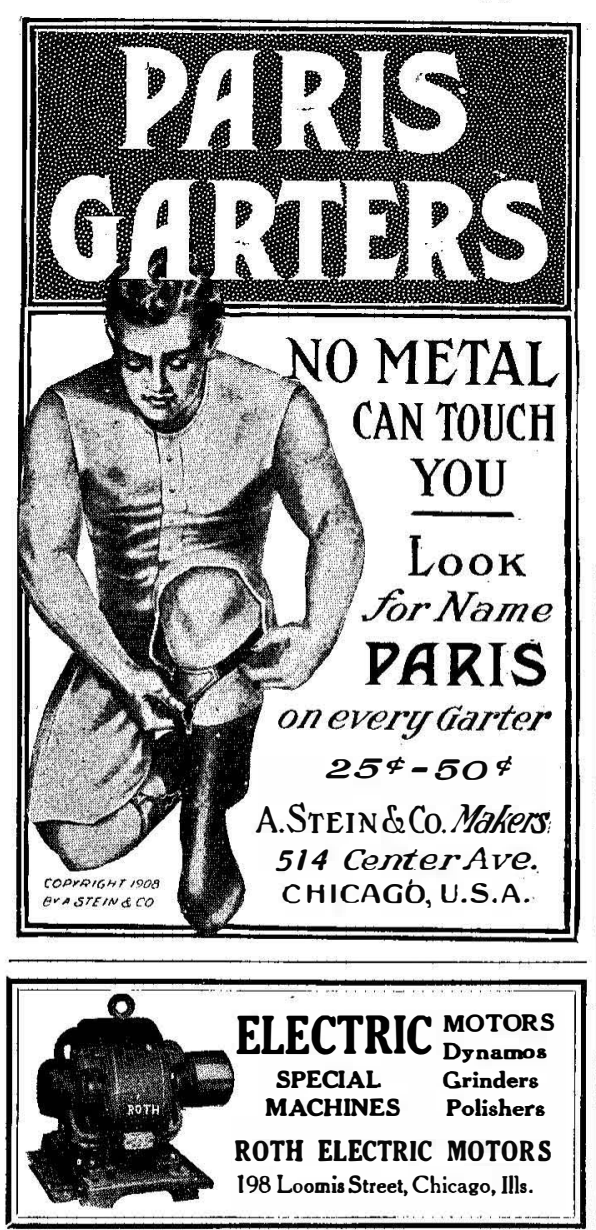

Magical Apparatus. $\omega c$, Parlor 'Tricks Catalogue, free.

G MACHINES Corliss Engines, Brewers' The VILTER MFG. CO.
899 Clinton Street,

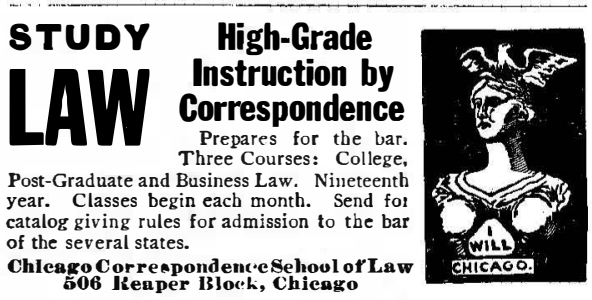

Incorporate
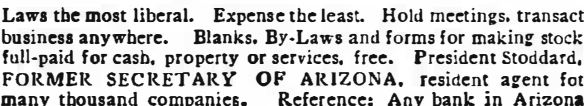

STODDARD INCORPORATING COMPANY, BOz 8000

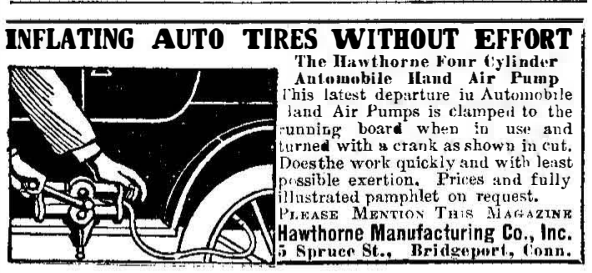

Send for This Puzzle To-day
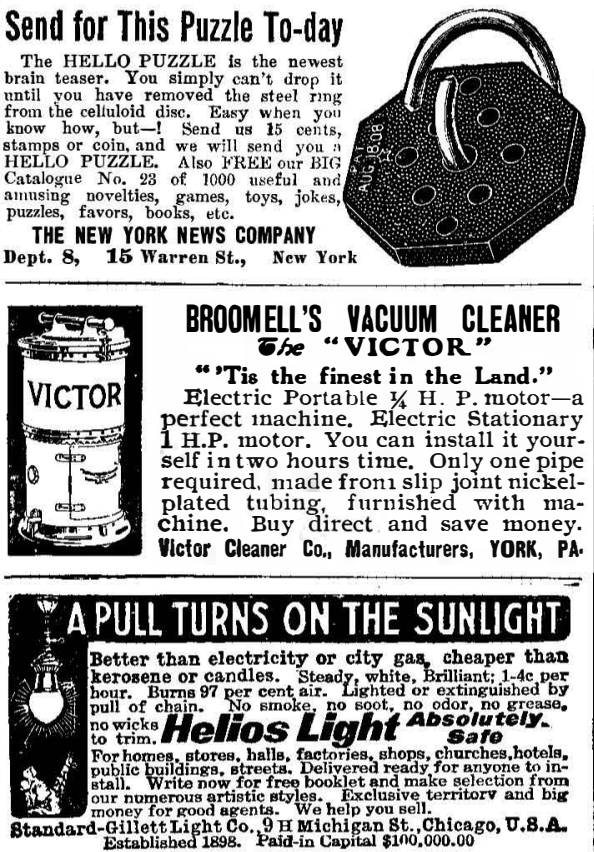
CRUDE ASBESTOS

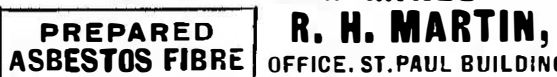
\begin{tabular}{|l|r|}
\hline ASBESTOS FIB RE & OFFICE. ST.PAUL BUILDING \\
tor Manufacturers use & 220 B' way, New York. \\
\hline
\end{tabular}

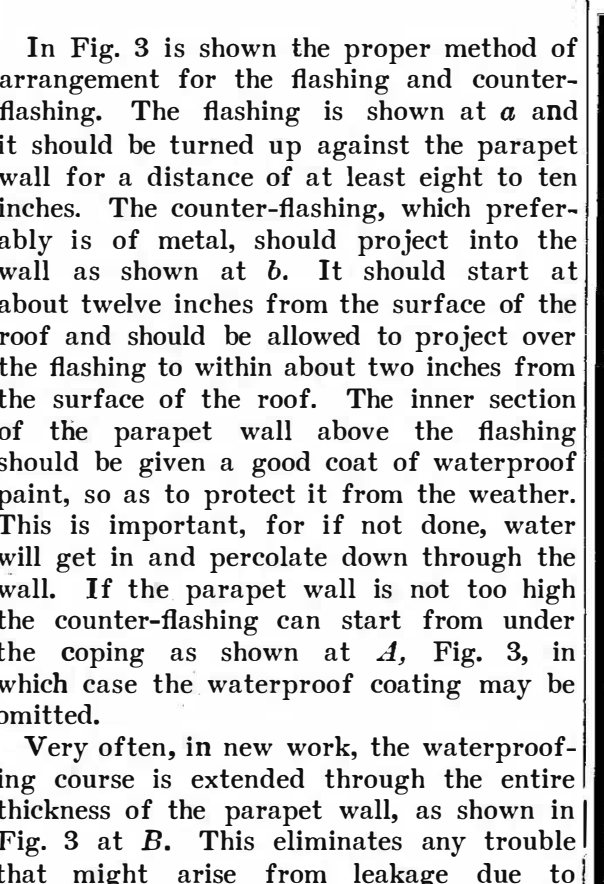

The electric vehicle is the real pleasure vehicle of the present and the future. The electric truck is the commercial car of the age-because of

\section{The Edison Storage Battery}

been made. Owners of Edison equipped trucks think nothing of sending them ingle charge of the battery. Edison Storage Battery are averaging also for specific information in regard and records of over 200 miles have in which you are most interested.

Edison Storage Battery Co., 132 Lakeside Ave., Orange, N. J. that might arise from leakage due moisture coming in above the flashing,
from any water that might get into the from any water that might get into the
wall through the joints in the coping. Aside from the roofing materials men tioned above, there are plastic roofing com-
positions which have given excellent results. These are applied with a trowel like morar and are more or less elastic in their of expansion and contraction. Aside from well, but as in the majority of readyroofing materials the ingredient used their composition is held as a secret. For the waterproofing of concrete swim-
ming pools, tanks, etc., a course of tar and ming pools, tanks, etc., a course of tar and felt or asphalt and felt may be employed, using the same general methods for appli-
cation as described for the waterproofing of foundations. If the tanks are well reinforced, so as to provide against expansion cracks, and a good rich mixture of concrete
is used, the integral method of waterproof ng, however, will produce good results. If leaks should develop owing to small expansion cracks, they can be completely paint applied to the inside of the tank. tank with a more or less lean mixture of apply to the inside surface of the walls apply to the inside surface of the walls
good rich cement mortar trowelect hard and smooth. Many incorporate into this coat one or the other of the many liquid or
powder forms of waterproofing compounds. This method has proved most successful, not only for tanks, but also for the repair-
ing of leaky cellar walls and floors. In ing of leaky cellar walls and floors. In
waterproofing, always remember that the waterproofing, no matter of what material, should always be applied to side of the
walls nearest the source whence the water comes. This in foundation walls is generally from the outside, and in tanks is alway
on the inside of the walls. In conclusion, it should be said that
weather conditions, as well as thorough weather conditions, as well as thorough final efficiency of waterproofing. Better results can always be obtained in warm weather than in cold. So bearing this fact in mind, never have waterproofing applied
in winter time, unless it is absolutely es-

\section{The Cement Market} (Continued from page gr8.)

blast furnaces. This was in 1901, in which year a process was discovered for making land cement. It could be produced cheape than the regular product, and the younger below its competitors. In 1901 this company turned out 200,000 barrels of Portland,
cement. Last year its output was 7,000,000 barrels. The addition of new machinery pany to turn out $10,000,000$ barrels this year, and by 1912 its annual output will ve reached $12,000,000$ barrels.

This competitor had for its field the entire Middle West. Peace reigned as long as the eastern companies kept out of that ern companies could not logically enter the western field. Freight rates would not percement did go into that territory, and it was not long before the young giant wa
forcing its ways into the eastern market. forcing its ways into the eastern market.
Prices were slashed right and left aft ln writing for our new catalog, ask

\section{AVIIIII CRUISES to the TOPo'theWORID During June, July and August}

Arrange your summer vacation to cover these delightful cruises. From Hamburg on the large twin-screw steamships BLUECHER, KRONPRINZESSIN CECILIE, METEOR - duration 13 to 24 days. Rates $\$ 62.50$ upwards. Visiting Norway, Spitzbergen, North Cape, celand, Scotland, Orkney and Faroe Islands and the seaside resorts of Europe.

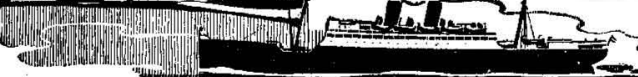

\section{Around theWorld Cruises}

Undes the most desirable conditions on the floating hotel S.S. CLEVELAND ( 17,000 tons), sailing from New York, November Duration 110 Days. Rates $\$ 650$ upwards; including all necessary expenses aboard and ashore. Visiting Madeira, Spain, Philippines, China, Japan, Sandwich lslands and Overland AmeriHAMBURG-AMERICAN LINE 41-45 Broadway, New York 1334 Walnut St. Philadelphis, 607 Boylston St. Boston, 159 Randoloh St.,
Chicago, 902 Olive St. St. Louis, 160 Powell St. San Francico. 338 SixthAve.,
Pittsburgh.
Offices in all the principal cities of the world

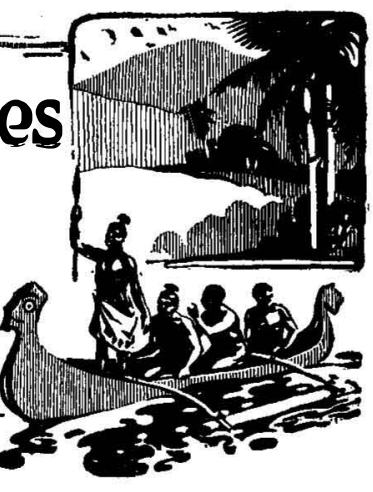

Artificial Stone for Building Trim PLANA And

Bush-hammered the same as natural stone, fully as durable and indistinguishable therefrom. Can be tinted to match any colored stone. We also prepare a superior quality of stucco, ready mixed with cement, for immediate application. Our facilities
enable us to make prompt shipments. \& For information as to prices, etc., address SIMPSON FAIR F I L D Q UAR I ES C OMPA N Quarries at LONG HILL, CONN. 45 Cedar Street, NEW YORK

F A DDC YOU CAN MAKE YOUR OWN FENCE POSTS FROM CEMENT I A RMIRS AT 15 TO 20 CENTS EACH. THEy WILl LAST A LIFETIME. POST MOLDS, \$12.0.0; BLOCK MACHINES, \$30.00; BRICK MACHINES, \$30.00. White Now for INTERSTATE MACHINERY COMPANY, 84 CAN BUREN ST.
1911 Catallogere.

\begin{tabular}{|c|c|}
\hline \multicolumn{2}{|c|}{ MR. HANDY-MAN'S WORK-BENCH } \\
\hline \multirow{3}{*}{1} & $\begin{array}{l}\text { is not complete without } \\
\text { PARKER'S PRESSED METAL CLAMP }\end{array}$ \\
\hline & $\begin{array}{l}\text { Replaces the antiquated, cumbersome, wood clamp. For mechanics, ma- } \\
\text { chinists, woodd-workers. Made in } 21 / 2 \text { in., } 3 \text { in., } 31 / 2 \text { in. sizes. Prices, } 25 \mathrm{c} \text {, } \\
35 \mathrm{c}, 45 \mathrm{c} \text {, respectively. Mailed post-paid on receipt of price. Special re- } \\
\text { duction when ordered in quantities. Liberal discount to dealers. }\end{array}$ \\
\hline & JOHN L. PARKER GO. \\
\hline
\end{tabular}

\section{Cement Pipe and Tile}

One of the big paying branches of the cement industry.

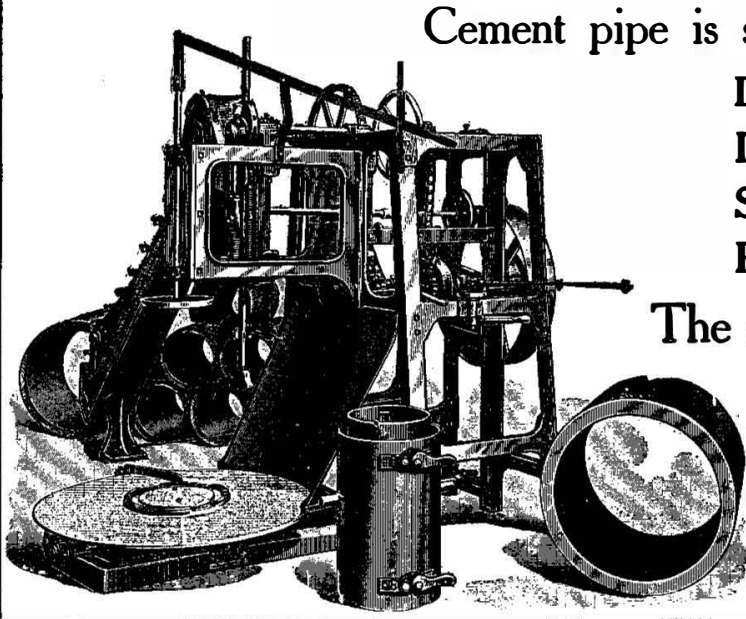

DRAINAGE

IRRIGATION

SEWERS

ROAD CULVERTS

The demand is great.

Catalog shows both hand and

MARSH CO.

967 Old Colony Building, Chicago

Power Machinery a specialty. 


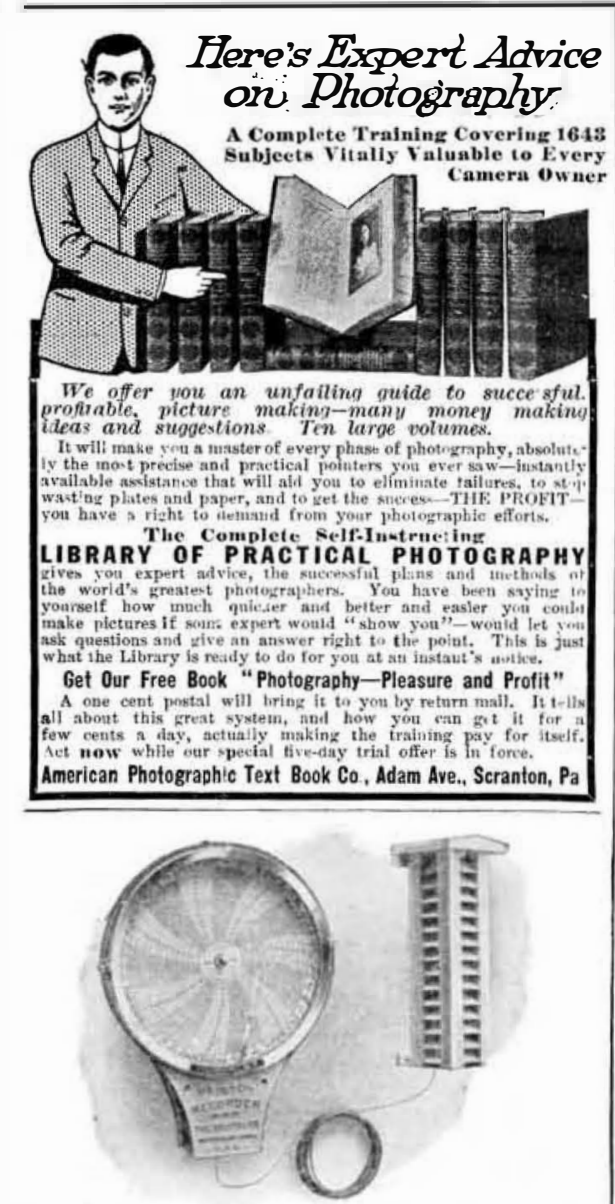

BRISTOL'S RECORDING THERMOMETERS

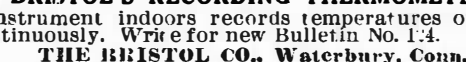

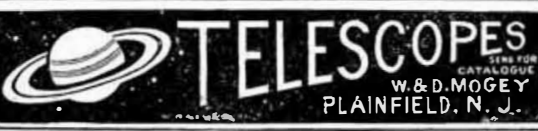

I WANT A

GOOD MAN

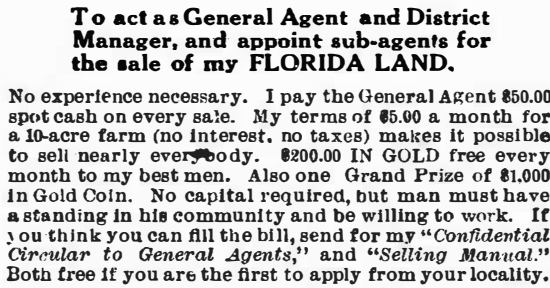

E. C. HOWE

104 Hartford Building, Chicago, III. BRASS and ALUMINUM CASTING Nith us for manufacture of your articles. Complete machine shop
Nickel plating, Japanning. Rotary File \& Machine Co
200 Diamond Street. Brooklyn, N. Y.

Too Much Florida Land Has Been Sold

To People Who Have Never Seen It.

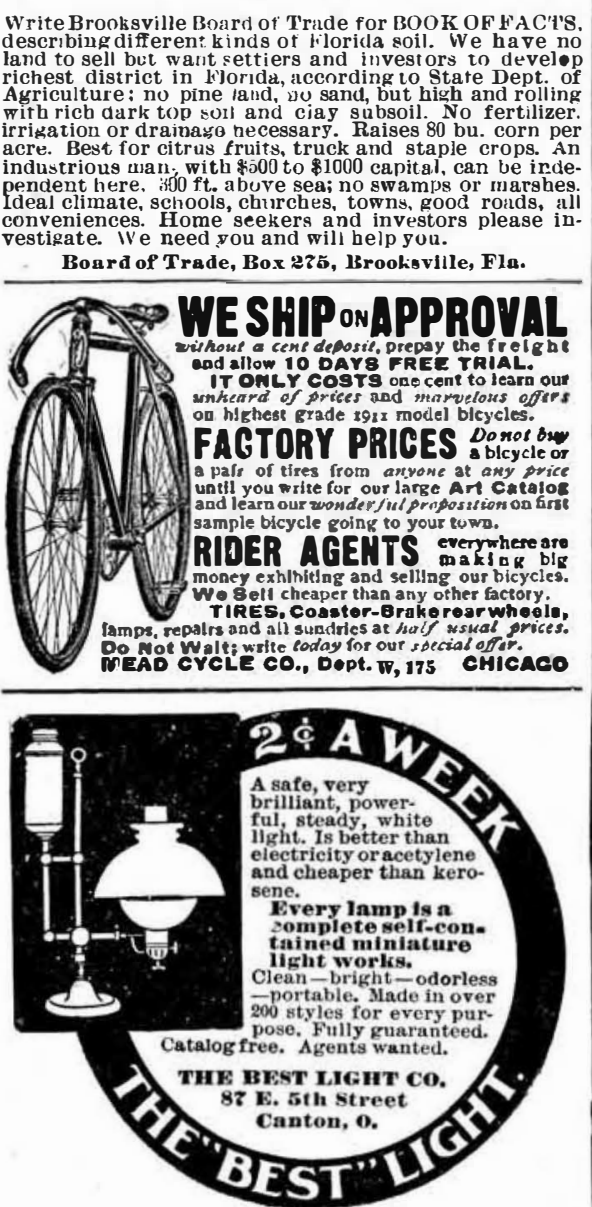

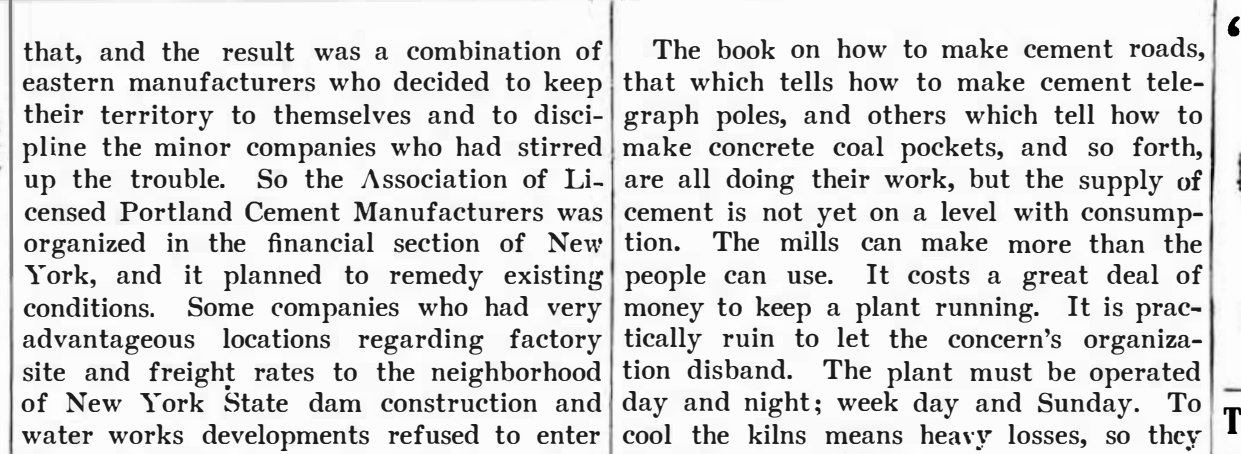

"STAR" LATHES

Large line of Attachments For Foot or Power

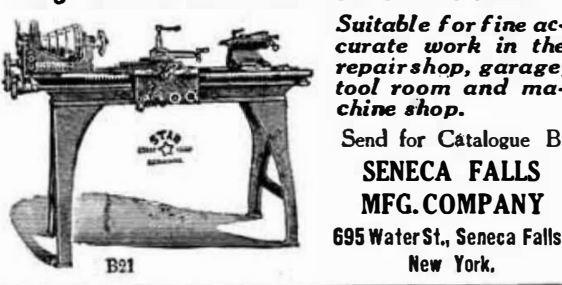

THE SEBASTIAN 15-INCH ENGINE LATHE HIGH GRADE ROW LOW PRICE
Automobile Builders. Garages, Repair and General Jobbing
Shops find this the ideal lathe for their work. Catalog free. WORK SHOPS and they were pledged to hold together turers cannot place it outside of this coununtil February 1st, 1911, but the association try. The exports last year were 2,340,000
disbanded on the thirty-first day of Decemscheduled to expire.
Prices immediately fluctuated. First $\begin{aligned} & \text { rels" to the Panama Canal. (The exact } \\ & \text { figures are computed at 2,100,000 barrels.) }\end{aligned}$ they were cut, then they were advanced ten Of this amount only 340,000 barrels, apcents a barrel, and finally about the end of point to a firm hand keeping the refractory companies in line so as to prevent them
from plunging themselves into the abyss of failure. One factor in the early disbanding of this association was an adverse decisio man patents under which there was an at tempt made to claim that practically $n$ country. This case is still pending, and final decision will help to clear the atmosphere in the whole trade.

During this period the cement companies were hard pushed to find profitable business. The Panama Canal work and the
Ashokan and Catskill dams, the Seaboard $\Lambda$ ir Line's railway over the Gulf from the
Florida mainlaund to Key West, all took large quantities, but the great need was for a steady outlet taking small quantities at time, but large q The secret of success in the Portland cement industry is to keep the entire equip-
ment busy to its full capacity. This reduces cost of manufacture. The question the arose, "How shall we get this small busiIt is a far cry from a sale totalling
$2,000,000$ barrels to the sale of a 100-pound bag of cement, but the manufacturer is
just as keen after the latter as he is for the former. To this business instinct of the cement producers must be largely ascribed
the credit of having created the improved
A merican farm. Here, then, is the required American farm. Here, then, is the require
new outlet. It works out about this way
The farm used to be a delapidated place The farm used to be a delapidated place
$\Lambda$ ny old thing would do; a stick for fence post, boughs for a culvert bridge, an
old tin roof for a pigsty and a shed for a cow barn. The farmer himself lived in a winter and baking hot in summer. The cultivator of the soil spent most of his winter store and idly gossiping about his neigh-
bors. To-day he reads in the free book of how
cement may be used on the farm. He is convinced and orders a bag of cement from
the general store in his town. He decides the general store in his town. He decide
he will try the experiment of making
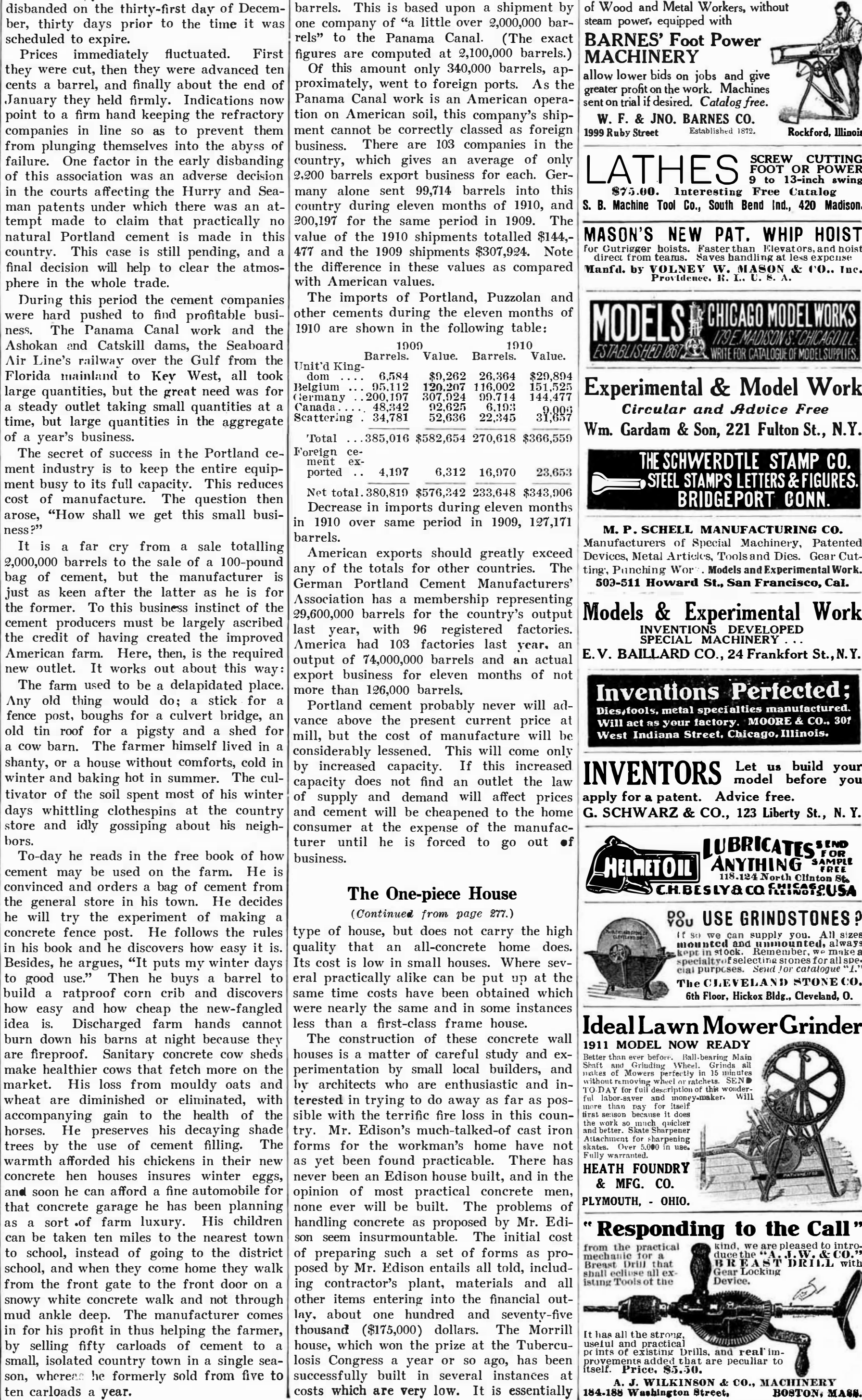
I $A T H F S \begin{aligned} & \text { SCREW CUTTING } \\ & \text { FOOT OR POWER } \\ & \text { to 13-inch } \text { swing }\end{aligned}$ S. B. Machine Tool Co., South Bend Ind., 420 Madison MASON'S NEW PAT. WHIP HOIST direct from teams. saves bandling at less expcuse
Vanfl. by VOLNEY W. MASON \& CO.. Inc.

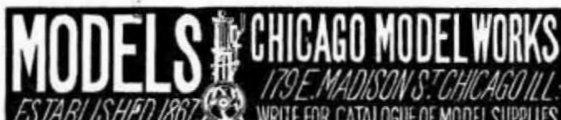

Experimental \& Model Work Circular and Advice Free

Wm. Gardam \& Son, 221 Fulton St., N.Y. THESGHWERDTLE STAMP CO. STEL STANPS LETIERS \& FIGURES BRDGEPORT BONK.

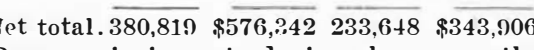
Decrease in imports during eleven months
1910 over same period in 1909, 127,171 Amels.

M. P. SCHELL MANUFACTURING CO.

xperimental Work

Models \& Experimental Work INVENTIONS DEVELOPED

E. V. BAILLARD CO., 24 Frankfort St., N. Y.

\section{Inventions Perfected;}

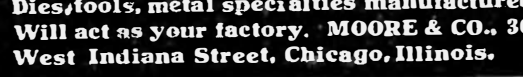

INVENTORS Let us build your iderably lessened. This will come capacity does not find If this increased of supply and demand will affect prices consumer at the expense of the manufac-
The One-piece House

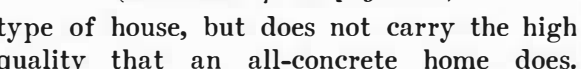

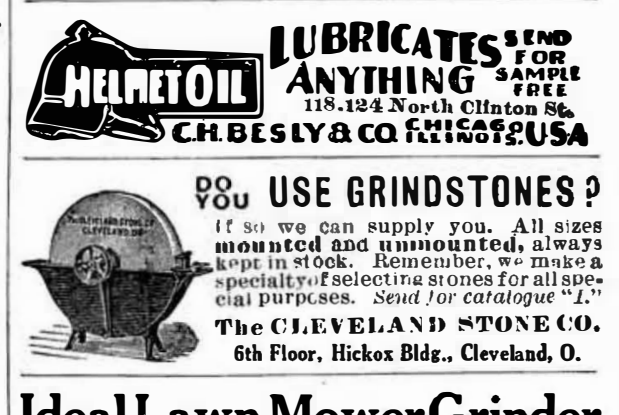

Ideal Lawn MowerGrinder
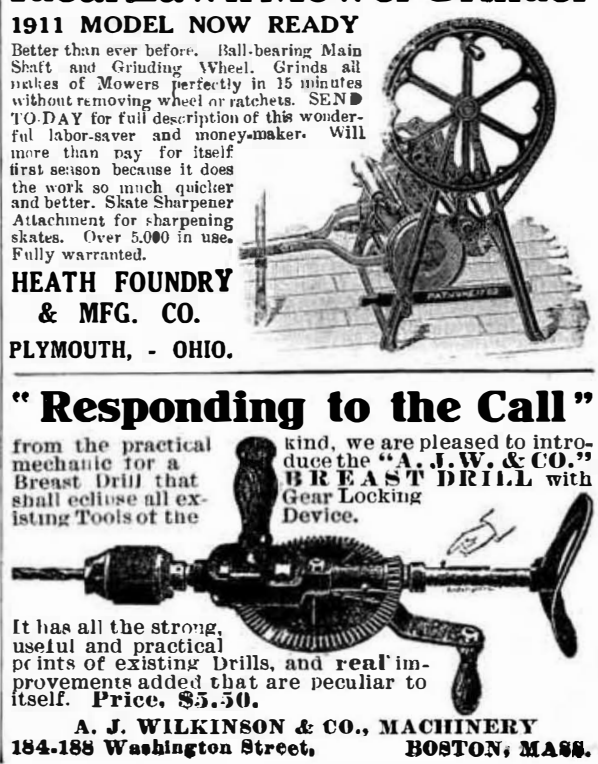